\title{
GENUS Sisymbrium L. (ROCKETS) IN THE FLORA OF LATVIA
}

\author{
leva Rūrāne $e^{\star \star \star * \#}$ and leva Roze ${ }^{\star *}$ \\ * Institute of Systematic Biology, Daugavpils University, Vienības iela 13, Daugavpils, LV-5401, LATVIA; \\ irurane@email.lubi.edu.lv \\ ** Institute of Biology, University of Latvia, Miera iela 3, Salaspils, LV-2169, LATVIA \\ \# Corresponding author
}

Communicated by Viesturs Melecis

One of the largest genera in the Cruciferae family in Latvia is Sisymbrium $L$. The genus includes not only native, but also some alien species. The distributions of the Sisymbrium species were reviewed for the first time in the last $50^{\text {th }}$ years in Latvia. The distribution data were compiled from herbarium material, literature and field surveys. An identification key for the Sisymbrium species in Latvia and detailed scientific nomenclature are presented in the current study. In total, seven species of Sisymbrium were found in Latvia - S. supinum L., S. loeselii L., S. polymorphum (Murray) Roth, S. volgense M. Bieb. ex E. Fourn., S. altissimum L., S. orientale L. and S. officinale (L.) Scop. The mainly were recorded in railway verges, roadsides, waste dumps and wasteland. Five species of the genus are alien to the flora of Latvia - S. loeselii, S. altissimum, $\mathrm{S}$. polymorphum, S. orientale, and S. volgense; two are native - S. supinum and S. officinale.

Key words: vascular plants, taxonomy, morphology, distribution, alien species.

\section{INTRODUCTION}

The Cruciferae Juss. family is widespread in the world and comprises about 390 genera and 3000 species. Cruciferae species mostly occur in the northern hemisphere from the meridionale to the boreale zone, and are most common in Mediterranean region. Sisymbrium L. is a large and heterogeneous genus and comprises about 94 species (Warwick et al., 2002), spread over the northern hemisphere from the meridionale to the boreale zone, also in southern parts of Africa and South America. Most of the species found in Central Europe are common in ruderal places close to inhabited areas, others like S. supinum L. occur in natural habitats, such as near river banks (Hegi, 1986).

Cruciferae is one of the largest families in Latvia and is represented by 47 genera. A large part of the species of the Cruciferae family in Latvia are alien species. Alien plants are those whose presence in a given area is due to intentional or unintentional human involvement, or which have arrived there without the help of people from an area in which they are alien (Pyšek et al., 2004). Distributions of alien species are affected by the types of entry to the territory and their preferred habitats. The Sisymbrium genus includes alien species with various distributions.

Data about the Sisymbrium genus appeared in Latvia in the second half of the 18th century in the work of natural scientist J. B. Fisher (Fischer, 1778; 1784; 1791). Research on the Latvian flora, including Sisymbrium, expanded in the 19th century. New plant species invaded Latvia due to di- rect human activity like transport networks or indirect human activity. The Latvijas PSR flora (Eleksis, 1955) describes three species of Sisymbrium and the list of taxa (Gavrilova and Šulcs, 1999) mentions seven species.

The last comprehensive analysis of the genus was done in the 1950s. However, the flora is constantly changing and it is necessary to update information about composition of plant species and the dynamics of their distribution in Latvia.

The aim of the present study was to revise the genus Sisymbrium in the flora of Latvia, by determining the range of taxa, diversity of morphological features and distribution patterns. The objectives were to produce an identification key for the species of genus Sisymbrium in Latvia, scientific nomenclature and original distribution maps in Latvia. The systematic study was performed according to the principles of preparation of the monograph Vascular Flora of Latvia (Šulcs, 2011).

\section{MATERIALS AND METHODS}

Herbarium material was investigated and field studies were performed in order to carry out a systematic study of the genus Sisymbrium. Herbarium material from the Laboratory of Botany, the Institute of Biology of University of Latvia (LATV), the Herbarium of the Museum of Botany of University of Latvia (RIG), the Herbarium of Slitere National park (SVR), the Herbarium of the Natural History Museum 
of Latvia (LDM), the Herbarium of the Daugavpils University (DAU), the Herbarium of the Latvia University of Agriculture (LLU), as well as private collections of botanists Alfrēds Rasiņš (RAS), Austra Āboliṇa (AB) and Kārlis $\bar{A}$ dolfs Veinbergs (VEINB), were examined. For species analyses, about 300 herbarium sheets were used. Field studies were based on the route method either selecting typical habitats of species or habitats where species could potentially be found.

Species descriptions were created based on Latvian plant material. Descriptions of species were elaborated with scientific nomenclature, description of habitats, distribution in Latvia and in the world. Distribution maps of geographical distribution in Latvia were compiled. These were prepared using the square method of geographical coordinates, where one square is approximately $7.6 \times 9.3 \mathrm{~km}$. The total numbers of squares in Latvia are 1017, of which 822 are completely located and 195 partly located in the territory of Latvia (Табака и др., 1980). Geographical distribution was characterised according to the geographical regions of Latvia - Coastal Lowland, Western Latvia, Central Latvia and Eastern Latvia (Ramans and Zelčs, 1995).

For species distribution, the evaluation scale accepted by Laboratory of Botany Institute of Biology was used: very rare (1-10 findings), rare (11-30), rather rare (31-100), not rare (101-250), rather frequent (251-500), frequent (501-750), very frequent (more than 751) (Fatare, 1992). Localities were marked in two ways on maps: - herbarium data, $\bigcirc$ - University of Latvia Institute of Biology lists of species. A question mark before a number of a square indicated that the square could not be accurately determined due to incomplete locality description.

Regarding nomenclature, authors for taxa are named in accordance with R. K. Brummit and C. E. Powell (1992). Authors who are not included in this work are named, written unabridged. Literary sources cited in the original language and abbreviations correspond to the accepted standard (Mill, 1993). For sources not included in this standard, abbreviations were formed using similar principles. The litera- ture cited are studies in which the taxon was mentioned for the first time in the Latvian flora, as well as Latvijas PSR flora (Eleksis, 1955); Flora USSR (Васильченко, 1939) and Flora Europaea (Ball, 1964).

Morphological characteristics are required in the analysis of genera and species. One of these characteristics is fruit diversity. In the family Cruciferae, fruits are very varied in shape and form. Typical fruit of the genus Sisymbrium is a siliqua, which is characterised by valves, surface, median vein and salience, as well as the length and thickness of style in relation to the siliqua. Sisymbrium valves are usually 3-veined. Siliqua are cylindrical or conical. The style is not longer than the width of siliqua. In the Cruciferae family, seeds can be located in one or two rows. In genus Sisymbrium these are in one row.

\section{RESULTS}

Species. Taxonomic analysis of the genus Sisymbrium indicated that seven species have been reported for Latvia $-S$. supinum L., S. loeselii L., S. polymorphum (Murray) Roth, $S$. volgense M. Bieb. ex E. Fourn., S. altissimum L., S. orientale L., and S. officinale (L.) Scop. Morphological characteristics of the Sisymbrium species are shown in Table 1 .

Diagnostic features. Diagnostic features are lower leaves, upper leaves, petals and siliqua. Inflorescence is a raceme. Flowers have sepals and petals, and are actinomorphic. There are four sepals: free, erect or patent, which are glabrous or with sparse hairs. There are four petals: free, yellow, rare white, clawed. Stamens are simple. External nectarial glands are ring-like around short stamens, with internal forming a ring. Ovary contains two carpels. Stigma is bilobed. Style is short or missing. Fruit is a siliqua with curved valves, with a clear median vein. Seeds are small and numerous. Leaves are pinnatifid to pinnatisect, entire, glabrous or with hairs. In Latvia they are annual and perennial herbs, in the world also small shrubs.

Table 1

A MORPHOLOGICAL DESCRIPTION OF SISYMBRIUM SPECIES

\begin{tabular}{|c|c|c|c|c|}
\hline & Lower leaves & Upper leaves & Petals & Siliqua \\
\hline S. supinum & \multicolumn{2}{|c|}{ all leaves pinnatisect, lobes oblong linear } & white & one in axil, curved \\
\hline S. officinale & \multicolumn{2}{|c|}{ all leaves pinnatisect, terminal lobe large } & yellow & conical, erect, appressed to the stem \\
\hline S. altissimum & pinnatisect, lateral lobes lanceolate & pinnatisect, lateral lobes linear & yellow & $\begin{array}{c}\text { outspread, horizontal, long, as thick as } \\
\text { pedicel }\end{array}$ \\
\hline S. orientale & pinnatifid & entire, oblong to lanceolate & yellow & outspread \\
\hline S. loeselii & \multicolumn{2}{|c|}{ all leaves pinnatifid to pinnatisect } & yellow & outspread \\
\hline S. volgense & $\begin{array}{c}\text { pinnatifid to pinnatisect, terminal lobe } \\
\text { large, hastate }\end{array}$ & entire, lanceolate, patent & yellow & appressed to the stem \\
\hline S. polymorphum & entire, oblong linear to linear, appressed & pinnatisect, terminal lobe large, ovate & yellow & outspread \\
\hline
\end{tabular}


Scientific nomenclature, distribution and habitat of the Sisymbrium species in Latvia

\section{Sisymbrium supinum L.}

Sisymbrium supinum L. 1753, Sp. Pl.: 657; P. W. Ball, 1964, Fl. Europ. 1: 264; Pētersone, 1980, in Pētersone un Birkmane, Latv. PSR augu noteic., 2. izd.: 142.

Braya supina (L.) W. D. J. Koch, 1837, Syn. Fl. Germ. 1: 50; Gautzsch, 1939, Korrbl. Naturf.-Ver. Riga, 63: 143; Eleksis, 1955, Latv. PSR Fl. 2: 380, in adnot.

Habitat. Lake shore, dolomite outcrop, ditch verge.

Distribution in Latvia. Very rare, at the bank of lake Kaṇieris in 1938 (14/21 V. Mühlenbach, RIG), in Lapmežciems 1957 (?13/22 L. Vìtoliṇa, LLU) (Fig. 1). In Latvia reaches eastern border of distribution area.

General distribution. Central Europe, Northwest Europe, temperate zone.

\section{Sisymbrium loeselii L.}

Sisymbrium loeselii L. 1755, Cent. Pl. 1: 18; J. Fisch. 1791, Vers. Naturg. Livl., 2. Aufl.: 557; Васильч. 1939, Фл. CCCP, 8: 44; Eleksis, 1955, Latv. PSR Fl. 2: 370; P. W. Ball, 1964, Fl. Europ. 1: 265.

Habitat. Weed-laden sites, railway verges, waste dumps, roadsides, weed in the gardens.

Distribution in Latvia. Alien species. Not rare, throughout the territory (Fig. 2).

General distribution. Europe, Caucasus, Western Asia, Central Asia, from meridionale zone to temperate zone. Alien species in North America.

\section{Sisymbrium polymorphum (Murray) Roth}

Sisymbrium polymorphum (Murray) Roth, 1830, Man. Bot. 2: 946; Васильч. 1939, Фл. СССР, 8: 46; Р. W. Ball, 1964, Fl. Europ. 1: 265; Фатаре, 1988, в Табака и др. Фл. сосуд. раст. Латв. ССР: 61.

Brassica polymorpha Murray, 1776, Novi Comment. Gotting. 7: 35.

Sisymbrium junceum (Willd.) M. Bieb. 1808, F1. Taur.-Cauc. 2: 114; Kuusk, Rasiņš, Jankevičienè, 1993, Fl. Balt. Countr. 1: 303.

Habitat. Railway tracks, railway embankments.

Distribution in Latvia. Alien species. Very rare, only one locality in Rīga, station Škirotava recorded in 1936 and 1937 (15/27, V. Mühlenbach, RIG) (Fig. 3).

General distribution. Eastern Europe, Southeastern Europe, Caucasus, Western Asia, Central Asia, Mongolia, submeridionale to temperate zone.

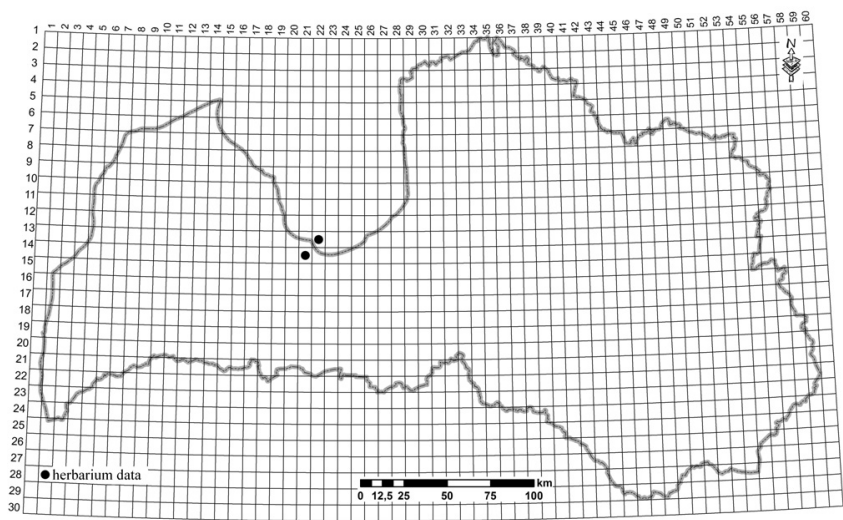

Fig. 1. Distribution of Sisymbrium supinum in Latvia.

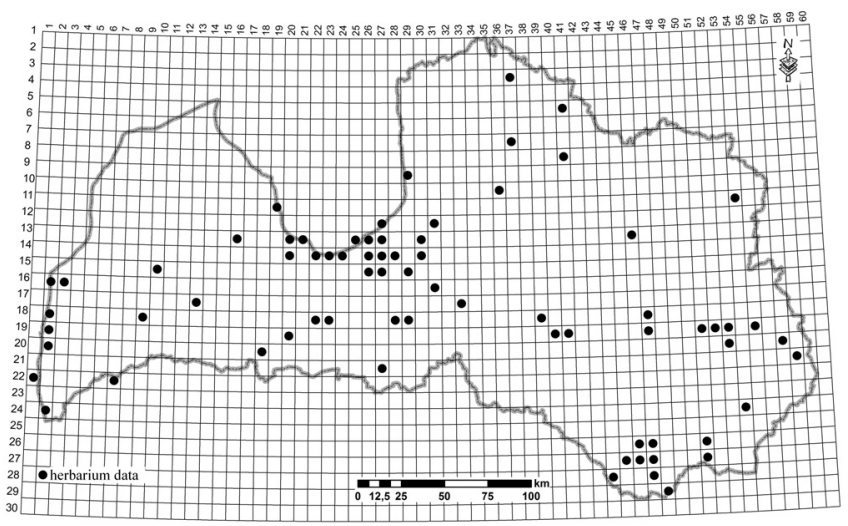

Fig. 2. Distribution of Sisymbrium loeselii in Latvia.

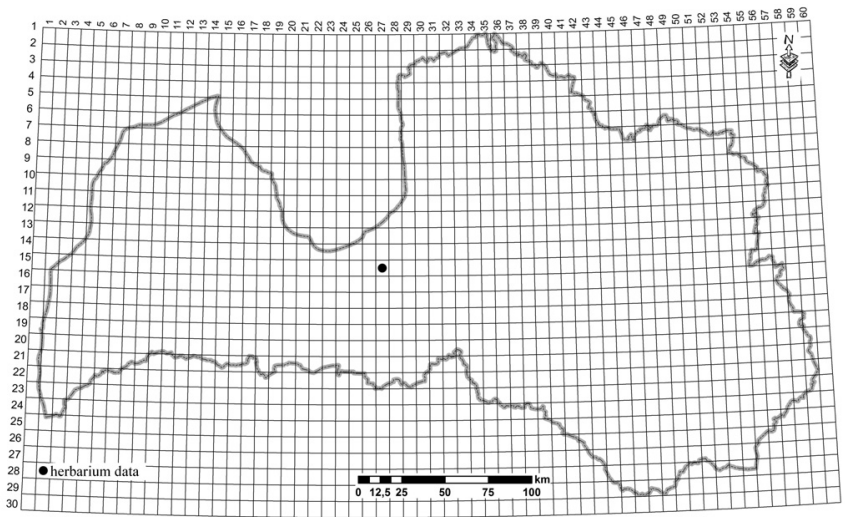

Fig. 3. Distribution of Sisymbrium polymorphum in Latvia.

\section{Sisymbrium volgense M. Bieb. ex E. Fourn.}

Sisymbrium volgense M. Bieb. ex E. Fourn. 1865, Rech. Fam. Crucif.: 97; E. Lehm. 1896, Nachtr. Poln.-Livl.: 86; Васильч. 1939, Фл. СССР, 8: 47; Eleksis, 1955, Latv. PSR Fl. 2: 380, in adnot.; P.W. Ball, 1964, Fl. Europ. 1: 265.

Habitat. Railway verges, roadsides, weed-laden sites.

Distribution in Latvia. Alien species. Rather rare, throughout the territory (Fig. 4). In Latvia northwest from distribution area.

General distribution. Eastern Europe, Western Asia, submeridionale zone. 


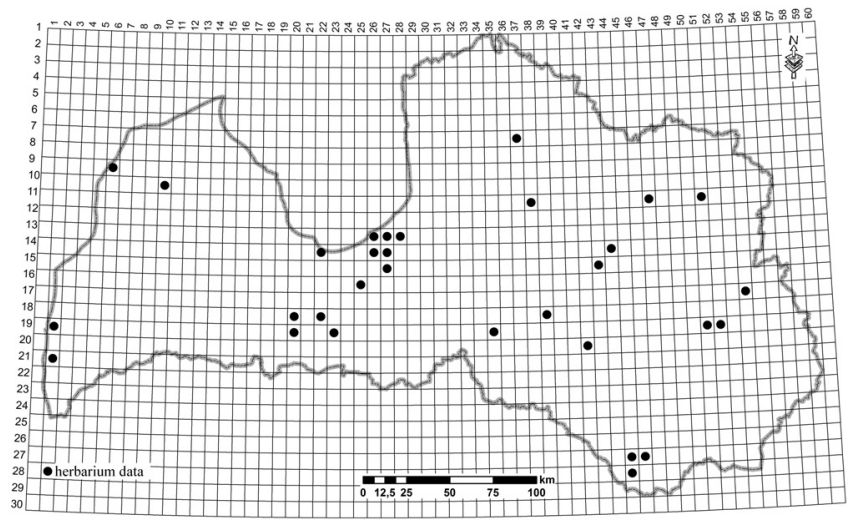

Fig. 4. Distribution of Sisymbrium volgense in Latvia.

\section{Sisymbrium altissimum L.}

Sisymbrium altissimum L. 1753, Sp. Pl.: 659; Mühlenbach, 1934, Acta Horti Bot. Univ. Latv. 7: 112; Васильч. 1939, Фл. СССР, 8: 49; Eleksis, 1955, Latv. PSR Fl. 2: 371; Р. W. Ball, 1964, Fl. Europ. 1: 265.

S. sinapistrum Crantz, 1769, Class. Crucif.: 138; Klinge, 1882, Fl. Est. Liv. Curl.: 396.

Habitat. Railway verges, roadsides, fallows, weed-laden sites.

Distribution in Latvia. Alien species. Not rare, throughout the territory (Fig. 5).

General distribution. Europe, except Southwestern Europe, Caucasus, Western Asia, from meridionale to boreale zone. Alien species in North America and South America.

\section{Sisymbrium orientale L.}

Sisymbrium orientale L. 1756, Cent. Pl. 2: 24; Mühlenbach, 1934, Acta Horti Bot. Univ. Latv. 7: 112; Васильч. 1939, Фл. СССР, 8: 50; P. W. Ball, 1964, Fl. Europ. 1: 265; Pētersone, 1980, in Pētersone un Birkmane, Latv. PSR augu noteic., 2. izd.: 143.

S. columnae Jacq. 1776, Fl. Austr. 4: 12; Rothert, 1915, Korrbl. Naturf.-Ver. Riga, 57: 86.

Habitat. Railway verges, roadsides, weed-laden sites.

Distribution in Latvia. Alien species. Very rare: Rīga (14/26, V. Rothert, 1911, RIG; 14/27, A. Šulcs, 1961, 1962, LDM), Valmiera (7/37, L. Melece, 1976, LATV) (Fig. 6).

General distribution. Central Europe, Eastern Europe (Ukraine), Caucasus, Asia Minor, Central Asia, meridionale and submeridionale zone.

\section{Sisymbrium officinale (L.) Scop.}

Sisymbrium officinale (L.) Scop. 1772, Fl. Carn. ed. 2, 2: 26; J. Fleisch. und Em. Lindem. 1839, in J. Fleisch., Fl. Esth. Liv. Kurl: 237; Васильч. 1939, Фл. СССР, 8: 52;

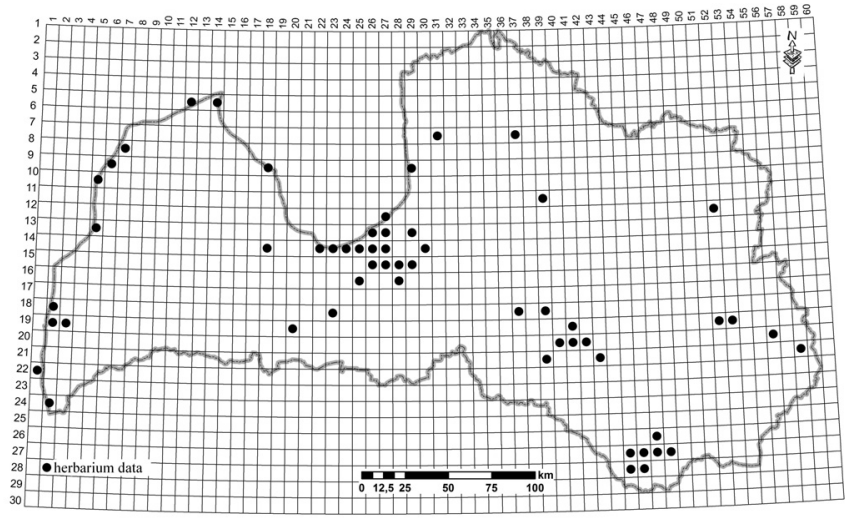

Fig. 5. Distribution of Sisymbrium altissimum in Latvia.

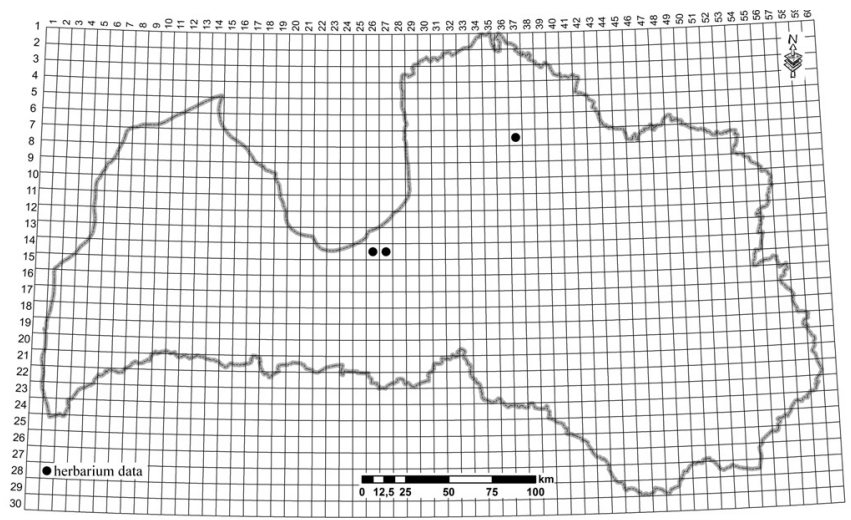

Fig. 6. Distribution of Sisymbrium orientale in Latvia.

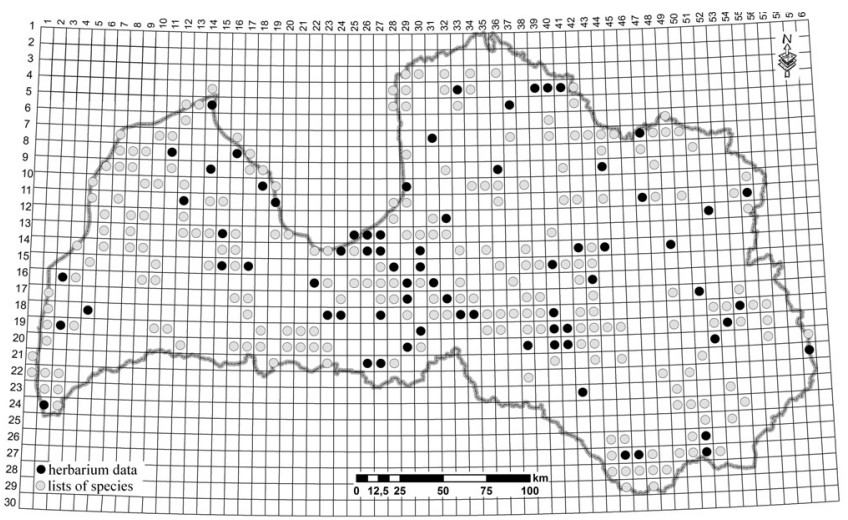

Fig. 7. Distribution of Sisymbrium officinale in Latvia.

Eleksis, 1955, Latv. PSR Fl. 2: 372; P. W. Ball, 1964, Fl. Europ. 1: 266.

Erysimum officinale L. 1753, Sp. Pl.: 660; J. Fisch. 1778, Vers. Naturg. Livl.: 265.

Habitat. Railway verges, roadsides, waste dumps, weedladen sites, weed in gardens and fields.

Distribution in Latvia. Frequent, throughout the territory (Fig. 7).

General distribution. Europe, Caucasus, West Asia, North Africa, from meridionale to boreale zone. Alien species in North America. 
LATVIAN NAMES OF SISYMBRIUM SPECIES

\begin{tabular}{|c|c|}
\hline S. supinum & zemā žodzene (Pētersone, 1980) \\
\hline S. officinale & $\begin{array}{l}\text { pērkones, pakūlains (Fleischer, 1830) } \\
\text { māju pērkoṇi (Arājs, 1902) } \\
\text { sētmalu sinepīte, mājas pērkoṇi (Bickis, 1920) } \\
\text { zālu slotzāle (Ašmanis, 1923) } \\
\text { mājas pērkoni, sētmalu sinepīte (Škipsna, 1931) } \\
\text { slotzāle, ķēernis, zosu zāle, tāle (Punka, 1934) } \\
\text { aptieku žodzenes (Galenieks, 1950) } \\
\text { ārstniecības žodzenes (Eleksis, 1955) } \\
\text { dziedniecības žodzenes (Pētersone, 1958) } \\
\text { ārstniecības žodzene (Saveljeva, Zumberga, 1960) } \\
\text { tauku zāle (Pētersone, 1961) } \\
\text { cel̦u žodzenes (Brastiňš, 1969) } \\
\text { dziedniecības žodzene (Pētersone, 1980) } \\
\text { parastā žodzene (Rasiňš, 1987) }\end{array}$ \\
\hline S. altissimum & $\begin{array}{l}\text { augstās žodzenes (Galenieks, 1950) } \\
\text { augstā žodzene (Galenieks, 1953) }\end{array}$ \\
\hline S. orientale & austrumu žodzene (Pētersone, 1980) \\
\hline S. loeselii & $\begin{array}{l}\text { Lezeḷa žodzenes (Galenieks, 1950) } \\
\text { Lēzel̦a žodzene (Rasinšs, 1954) } \\
\text { Lēzela žodzene (Lejiňš et al., 1997) }\end{array}$ \\
\hline S. volgense & Volgas žodzene (Saveljeva, Zumberga, 1960) \\
\hline S. polymorphum & daudzveidīgā žodzene (Fatare, 1998) \\
\hline
\end{tabular}

Accepted Latvian names are marked in bold.

In the study of genus Sisymbrium Latvian names were also examined (Table 2). For species S. altissimum which had previous both plural and singular names, the singular was accepted, because the Latin name is in singular. For several species there is no variability in Latvian names used, like $S$. supinum, S. orientale, S. volgense and S. polymorphum. Species $S$. orientale, $S$. volgense and $S$. polymorphum are alien and there distributions are very rare to rather rare, which perhaps is the reason a diversity of species names did not occur. S. supinum is also a very rare species. In most cases, species Latvian names are translations from Latin. Priority was given to names approved by the terminology commission and if they complied with the requirements of systematics. Species accepted names in Table 2 are shown in bold.

\section{DISCUSSION}

The first record of the genus Sisymbrium in the flora of Latvia was from 1778 when J. Fischer (1778) mentioned Erysimum officinale L. (=Sisymbrium officinale). S. officinale is distributed throughout Europe (Ball, 1964). Its main distribution range is in the temperate zone in Europe, where it is common in ruderal plant communities (Hegi, 1986). In Latvijas PSR flora (Eleksis, 1955) S. officinale is mentioned as frequent and now $S$. officinale is found throughout the territory.

In 1791, J. Fischer described another species, S. loeselii (Fischer, 1791). V. Mühlenbach (1934) reported that $S$. loeselii was very frequent around many railway stations in Rìga. S. loeselii is common in Central and Eastern Europe, often introduced in the Western Europe and Northern Europe (Ball, 1964). A. Eleksis (1955) mentioned that $S$. loeselii is rare but that it had become more frequent.

J. Klinge (1882) added another species, S. sinapistrum Crantz. (=S. altissimum), to the genus, and pointed out that it had spread extensively and can be considered as naturalised. V. Mühlenbach (1934) also confirmed widespread distribution of $S$. altissimum in Rīga. A. Eleksis (1955) mentioned that $S$. altissimum is not rare and occurs along roads and is relatively common in adjacent areas of large cities throughout the territory.

S. volgense was mentioned by E. Lehmann in 1896 as an alien species to Latvia, which spread with crop seed from the Volga steppe areas. S. volgense was found in some places in Rīga, where it formed smaller or larger populations (Mühlenbach, 1934; Шулц, 1976). In Latvijas PSR flora (Eleksis, 1955) it was mentioned that $S$. volgense was once found in Latvia, but had disappeared. Analysis of herbarium material established new $S$. volgense localities in Latvia. S. volgense tended to increase in occurrence of frequency in Latvia and is found mostly near large cities and towns- Rīga, Liepāja, Dobele, Valmiera, Gulbene, Madona, Pḷaviṇas, Daugavpils, Rēzekne, and Balvi, mainly at railway stations and around anthropogenic habitats. It has become locally naturalised in many European countries and is native to South-Western Russia. In the native area of $S$. volgense, it grows in the steppe as a weed, from where this species has dispersed by wind along railway lines (Oprea and Sīrbu, 2010). In Europe, S. volgense is found on railway embankments and in stations, harbours, along roads, ruderal areas, around homes, and in fields (Bojnanský and Fargašová, 2007).

V. Rothert (1915) added S. columnae Jacq. (=S. orientale) to the flora. It was found at the Riga freight station. $S$. orientale was found again in 1961 and 1962 in Rìga (Шулц, 1977). S. orientale occurs in Southern Europe and frequently is introduced elsewhere (Ball, 1964). In Central Europe $S$. orientale is alien and scattered on ruderal sites (Hegi, 1986).

O. Gautzsch (1939) mentioned Braya supina (L.) W. D. J. Koch (=S. supinum), which was found around Kemeri in 1937 and on the shore of Kanieris lake in 1938 (Mühlenbach, 1985). The locality was destroyed by changing of the water level in the lake (Fatare, 2003). Herbarium records indicate that $S$. supinum was last found in 1957 in Lapmežciems. S. supinum is found in Estonia where it occurs on rocky shores (Kukk, 1999), in quarries and along roadsides (Kukk and Kull 2005). S. supinum is included in the Red Data Book of Latvia (Fatare, 2003) as well as in the Red Data Book of the Baltic Region (Ingelög et al., 1993) and in the Council Directive on the conservation of natural habitats and of wild fauna and flora (Anonymous, 1992). S. supinum is an extinct species in Latvia and only two localities, in the Coastal Lowland, have been recorded. It is possible that its rarity may be due to unsuitable soil conditions. In Öland, 
Sweden $S$. supinum is found in dry grasslands containing several fruticose lichens (Löbel and Dengler, 2008).

S. polymorphum was first mentioned in the literature only in the second half of the 20th century, in the list of Vascular flora of Latvia, as an alien species (Фатаре, 1988). Herbarium analysis confirmed $S$. polymorphum in the flora of Latvia. It is perhaps occasionally introduced by rail transit. Herbarium material was collected in 1936 and 1937 in Rīga, in the surroundings of the Škirotava railway station, which is its only known locality. S. polymorphum is native to Eastern Europe, on steppe and stony slopes, in forests, river terrace, fields and ruderal stands (Bojnanský and Fargašová, 2007). In Lithuania, the list of Sisymbrium species is very similar to the species in Latvia and also S. altissimum, $S$. loeselii, S. orientale, S. polymorphum and S. volgense are defined as alien species (Gudžinskas, 1997). In Estonia, the Sisymbrium species are S. altissimum, S. loeselii, $S$. officinale, $S$. supinum and $S$. volgense. Species $S$. altissimum, $S$. loeselii and $S$. volgense are considered also as alien. (Kukk and Kull 2005).

Current taxonomic analysis of genus showed that there are seven species in the flora of Latvia. S. loeselii, $S$. altissimum, $S$. officinale, $S$. polymorphum, $S$. orientale, and $S$. volgense are mainly found on railway verges, roadsides, waste dumps and wasteland. S. supinum is very rare, found on lake shores, and recorded for the last time in the 1950s, around Lapmežciems. Five species of the genus are alien to the flora of Latvia - S. loeselii, S. altissimum, S. polymorphum, S. orientale, and S. volgense. The distribution of these species varies considerably. Some of them have become relatively common - S. loeselii, $S$. altissimum, $S$. volgense. S. polymorphum is considered as an ephemerophyte, and has not been recorded after 1937. As this species has been introduced accidentally, its re-finding is unlikely, but not excluded.

\section{ACKNOWLEDGEMENTS}

The authors wish to thank Viesturs Šulcs for valuable comments on the manuscript and Juris Soms for the opportunity to use the maps layers.

\section{REFERENCES}

Anonymous (1992). Council Directive 92/43/EEC of 21 May 1992 on the conservation of natural habitats and of wild fauna and flora. http://eur-lex.europa.eu/legal-content/EN/TXT/?uri=CELEX:31992L0043 (last accessed 10 April 2015).

Arājs, F. (1902). Dārzkopja vārdnīca: Latviski augu nosaukumi [Gardeners Dictionary: Latvian plant names]. Dārzkopju padomnieks: Dārzkopības rakstu krājums, 10, 116-123. (in Latvian).

Ašmanis, K. (1923). Latvijas flora: Ziedaugu noteicējs, sabiedrības kalendārs līdz ar bišu, tehniskiem, ārstniecības un krāšn,umaugiem [Latvian Flora: Determination of Flowering Plants, Community Calendar and a Bee, Technical, Medical and Ornamental Plants]. Rīga: Valters un Rapa. 320 lpp. (in Latvian).

Ball, P. W. (1964). Sisymbrium L. In: Tutin, T. G., Heywood, V. H., Burges, N. A., Valentine, D. H., Walters, S. M., Webb, D. A. (eds.). Flora Europaea. Vol. 1. (pp. 264-266). Cambridge: University Press.
Bickis [Bitzky], J. (1920). Latvijas augu noteicējs [Key of Latvian Plants]. 2. dậa. Cēsis: Skola. 104 lpp. (in Latvian).

Bojnanský, V., Fargašová, A. (2007). Atlas of Seeds and Fruits of Central and East-European Flora: The Carpathian Mountains Region. Dordrecht: Springer. $1046 \mathrm{pp}$.

Brastiņš, A. (1969). Pērkons: pērkons dainās, mīklās un parunās [Thunder: Thunder in Latvian folk-songs, riddles and sayings]. Labietis: laikraksts latvietībai, 37, 691-709 (in Latvian).

Brummitt, R. K., Powell, C. E. (eds.) (1992). Authors of Plant Names. Kew: Royal Botanic Gardens. 732 pp.

Eleksis, A. (1955). Žodzenes - Sisymbrium L. [Rockets - Sisymbrium L.] In: Galenieks, P. (ed.). Latvijas PSR flora. 2. sēj. (370.-374. lpp.). Rīga: Latvijas Valsts izdevnieciba (in Latvian).

Fatare, I. (1992). Latvijas floras komponentu izplatības analīze un tās nozīme augu sugu aizsardzības koncepcijas izstrādāšanā [The study of distribution of Latvian autochthonous floral components and its importance in developing a conception on plant species protection]. Rìga: Zinātne. 259 lpp. (in Latvian).

Fatare, I. (1998). Žodzenes [Sisymbrium L.] In: Kavacs, G. (ed.). Latvijas daba: Enciklopēdija. 6. sēj. (162.-163. lpp.). Rìga: Preses nams (in Latvian).

Fatare, I. (2003). Sisymbrium supinum L. In: Andrušaitis, G. (ed.). Red Data Book of Latvia (pp. 34-35). Rīga: LU Bioloğijas institūts.

Fischer, J. B. (1778). Versuch einer Naturgeschichte von Livland. Leipzig: J. G. I. Breitkopf. $375 \mathrm{~S}$.

Fischer, J. B. (1784). Zusäze zu seinem Versuch einer Naturgeschichte von Livland. Riga: J. F. Hartknoch. 159 S.

Fischer, J. B. (1791). Versuch einer Naturgeschichte von Livland. 2. Aufl. Königsberg: F. Nicolovius. XXIV, $826 \mathrm{~S}$.

Fleischer, J. G. (1830). Systematisches Verzeichnis der in der OstseeProvinzen bis jetzt bekannt gewordenen Phanerogamen, mit Angabe der gebräuchlichsten deutschen, lettischen und ehstnischen Benennungen. Mitau: Schabert. 120 S.

Galenieks, P. (1950). Botāniskā vārdnīca: Augu ğinšu un sugu latvisko, krievisko un latinisko nosaukumu krājums [Botanical Dictionary: Plant Genera and Species Names Collection in Latvian, Russian, and Latin]. Rīga: Latvijas Valsts izdevniecība. 219 lpp. (in Latvian).

Galenieks, F. (1953). Krievu - latviešu lauksaimniecības vārdnīca [Russian - Latvian agricultural dictionary]. Rīga: Latvijas Valsts izdevniecība. 426 lpp. (in Latvian).

Gautzsch, O. (1939). Floristische Notizen. Korrespondenzblatt des Naturforscher-Vereins zu Riga, 63, 142-144.

Gavrilova, G., Šulcs, V. (1999). Flora of Latvian vascular plants: List of taxa. Riga: Institute of Biology of University of Latvia. $136 \mathrm{pp}$.

Gudžinskas, Z. (1997). Conspectus of alien plant species of Lithuania. 3. Brassicaceae. Botanica Lithuanica, 3 (3), 215-249.

Hegi, G. (1986). Sisymbrium L. Rauke. In: Conert, H. J., Hamann, U., Schultze-Motel, W., Wagenitz, G. (eds.). Illustrierte Flora von Mitteleuropa. Angiospermae: Dicotyledones 2, 4 (1) (S. 94-112). Berlin, Hamburg: Verlag Paul Parey.

Ingelög, T., Andersson, R., Tjernberg M. (eds.) (1993). Red Data Book of the Baltic Region. Uppsala, Riga: Swedish Threatened Species Unit, Institute of Biology. 95 pp.

Klinge, J. (1882). Flora von Est-, Liv- und Curland. Reval: Verlag von Franz Kluge. $664 \mathrm{~S}$.

Kukk, T. (1999). Eesti taimestik. Tartu, Tallin: Teaduste Akadeemia Kirjastus. 464 pp. (in Estonian).

Kukk, T., Kull, T. (eds.) (2005). Atlas of the Estonian Flora. Tartu: Institute of Agricultural and Environmental Sciences of the Estonian University of Life Sciences. 528 pp.

Lehmann, E. (1896). Nachtrag zur Flora von Polnisch-Livland. Jurjew (Dorpat): Druck von C. Mattiesen. $125 \mathrm{~S}$. 
Lejinšs, A., Rasiṇš, A., Āboliṇš, J., Gavrilova, G̣., Lapinšs, D., Ozols, J., Vimba, E. (1997). Nezāḷu, to grupu un augu aizsardzības tehnikas terminologíjas vārdnīca [Terminology Dictionary of Weeds, Their Groups and Technique of Plant Protection]. Skrīveri: Agra. 300 lpp. (in Latvian).

Löbel, S., Dengler, J. (2008). Dry grassland communities on southern Öland: phytosociology, ecology, and diversity. Acta Phytogeogr. Suec., 88, $13-31$.

Mill, R. R. (ed.) (1993). Appendix II: Key to the abbreviations of titles of books cited in Volume 1; Appendix III: Key to the abbreviations of titles of periodicals and anonymous works cited in Volume 1. In: Tutin, T. G., Burges, N. A., Chater, A. O., Edmondson, J. R., Heywood, V. H., Moore, D. M., Valentine, D. H., Walters, S. M., Webb, D. A. (eds.). Flora Europaea. Vol. 1. $2^{\text {nd }}$. edn. (pp. 480-522). Cambridge: University Press.

Mühlenbach, V. (1934). Die Adventivflora des Rigaer Eisenbahnknotens. Acta Horti Botanici Universitatis Latviensis, 7, 87-130.

Mühlenbach, V. (1985). Reflections of an oldtimer on the flora of Latvia. Phytologia, 58 (5), 305-323.

Oprea, A., Sîrbu, C. (2010). Sisymbrium volgense (Brassicaceae) in the flora of Romania. Analele Universității din Oradea - Fascicula Biologie, 17 (2), 296-299.

Pētersone, A. (1958). Žodzenes - Sisymbrium L. [Rockets - Sisymbrium L.] In: Pētersone, A., Birkmane, K. Latvijas PSR augu noteicējs (334.-335. lpp.). Rīga: Latvijas Valsts izdevniecība (in Latvian).

Pētersone, A. (1961). Savval̦as ārstniecības augi [Wild herbs]. Rīga: Latvijas Valsts izdevniecība. 459 lpp. (in Latvian).

Pētersone, A. (1980). Žodzenes - Sisymbrium L. [Rockets - Sisymbrium L.] In: Pētersone, A., Birkmane, K. Latvijas PSR augu noteicējs. 2. izd. (142.-144. 1pp.). Rīga: Zvaigzne (in Latvian).

Punka, J. (1934). Latviski un latīniski zāḷ augu nosaukumi: farmaceitiem, drogistiem un citiem zāḷ augu cienìtājiem [Latvian and Latin Names of Medical plants for Pharmacists, Druggists and Other Fanciers of Medicinal Plants]. Rīga: Rūḳis. 77 lpp. (in Latvian).

Pyšek, P., Richardson, D. M., Rejmánek, M., Webster, G. L., Williamson, M., Kirschner, J. (2004). Alien plants in checklists and floras: Towards better communication between taxonomists and ecologists. Taxon, 53 (1), 131-143.

Ramans, K., Zelčs, V. (1995). Fizioǵeogrāfiskā rajonēšana [Geographical division of regions]. In: Kavacs, G. (ed.). Latvijas daba: Enciklopēdija. 2. sēj. (74.-76. lpp.). Rīga: Latvijas enciklopēdija (in Latvian).

Rasin̦š, A. (1954). Latvijas PSR nezāḷ augḷi un sēklas [Latvian SSR Weed Seeds and Fruits]. Rīga: Latvijas Valsts izdevniecība. 424 lpp. (in Latvian).
Rasin̦š, A. (1987). Svarīgāko tīrumu un dārzu nezāḷ noteicējs pēc viegli ievērojamām pazīmēm [Key for the Most Important Field and Garden Weeds following Easily Observable Features]. Rīga: Latvijas PSR Valsts agrorūpnieciskā komiteja. Zinātniski tehniskās informācijas pārvalde. 44 lpp. (in Latvian).

Rothert, V. (1915). Die Flora des Rigaer Zentralgüterbahnhofs. Korr. Naturforsch. Ver. Riga, 57, 79-93.

Saveljeva, J., Zumberga, M. (eds.) (1960). Augu aizsardzība. Zinātniskā un tehniskā terminologija [Plant Protection. Scientific and Technical Terminology]. Nr. 3. Latvijas PSR Zinātṇu akadēmija Terminoloǵijas komisija. Rīga: Latvijas PSR Zinātṇu akadēmijas izdevniecība. 591 lpp. (in Latvian).

Škikipsna, A. (1931). Materiāli ziedaugu latviskiem nosaukumiem [Materials for Latvian Flowering Plant Names]. Diplomdarbs (rokraksts). Rīga. 198 lpp. (in Latvian).

Šulcs, V. (2011). Latvijas vaskulāro augu floras sagatavošanas principi [Principles of preparation for vascular flora of Latvia]. In: Gavrilova, G. Latvijas vaskulāro augu flora 11: Glīvene-Potamogeton (Potamogetonaceae) (VII-XIV). Rīga: Latvijas Universitātes Bioloğijas institūts (in Latvian).

Warwick, S. I., Al-Shehbaz, I. A., Robert, A. P., Sauder, C. (2002). Phylogeny of Sisymbrium based on ITS sequences of nuclear ribosomal DNA. Can. J. Bot., 80, 1002-1017.

Васильченко И.Т. (1939). Гулявник - Sisymbrium L. [Vasilczeko, I. T. Rocket - Sisymbrium L.] В кн.: Комаров В. Л., Буш Н. А. (ред.). Флора CCCP, Т. 8 (c. 38-55). Москва, Ленинград: Издательство Академии Наук CCCP (in Russian).

Фатаре И. (1988). Sisymbrium L. [Fatare, I. Sisymbrium L.]. В кн.: Табака Л., Гаврилова Г., Фатаре И. Флора cocyдистых растений Латвийской ССР (с. 53-62). Рига: Зинатне (in Russian).

Табака Л. В., Клявиня Г. Б., Фатаре И. Я. (1980). Метод картирования флоры Латвийской ССР и его использование при составлении „Атласа флоры Европы” [Tabaka, L. V., Кпаviта, G. B., Fatare, I. J. Mapping method of the flora of Latvian SSR and using it for comprising "Atlas Flora Europaeae"]. В кн.: Тихомиров В. Н. (ред.). Картирование ареалов видов флоры европейской части СССР (с. 21-24). Москва: Наука (in Russian).

Шулц А. (1976). Адвентивная флора на территории железнодорожных узлов г. Риги [Schultz, A. Adventive flora on the territory of Riga railway junctions]. Бот. журн., 61 (10), 1445-1454. (in Russian).

Шулц А. (1977). Адвентивная флора города Риги [Schultz, A. Adventive flora of Riga city]. Бот. журн., 62 (10), 1513-1523. (in Russian).

Received 2 August 2014

\section{ŽODZEN̦U G̦INTS Sisymbrium L. LATVIJAS FLORĀ}

Sugu skaita ziṇā Latvijā viena no lielākajām g̛intīm krustziežu Cruciferae Juss. dzimtā ir žodzeṇu ğints Sisymbrium L., un šajā g̛intī ir ne tikai vietējās, bet arī adventīvās sugas. Pirmo reizi pēdējo 50 gadu laikā analizēta Sisymbrium sugu izplatība mūsu valsts teritorijā. Izplatības dati iegūti no herbārija datiem, literatūras un lauka pētījumiem. Sisymbrium sugām Latvijā sastādīta noteikšanas tabula un zinātniskā nomenklatūra. Latvijā konstatētas septiṇas Sisymbrium sugas — zemā žodzene S. supinum L., Lēzela žodzene S. loeselii L., daudzveidīgā žodzene S. polymorphum (Murray) Roth, Volgas žodzene S. volgense M. Bieb. ex E. Fourn., augstā žodzene $S$. altissimum L., austrumu žodzene $S$. orientale L. un ārstniecības žodzene S. officinale (L.) Scop., kuras galvenokārt sastopamas uz dzelzceḷa, ielu malās, izgāztuvēs un nezālienēs. 